\title{
Optimization of Teachers Working Group for The Development of Professionalism In School Cluster
}

\author{
Dhina Luvitasari ${ }^{1}$ \\ ${ }^{1}$ (Malang State University, East Java)
}

\begin{abstract}
Teachers are the most important element in the national education system that was developed to organize the teaching, coaching and training for educators. Whether or not a school or a curriculum is highly dependent on the quality of teachers. For those reasons, the teacher must always be developed so that the quality of learning ability can be maintained and improved. The system of professional development of teachers can be made through the group through the forum Teacher Working Group.This study aims to find a substantive theory related to the professional development of teachers is lifted from three research sites in the area is difficult to reach. The focus of the study include: (1) the work program Teachers Working Group, which includes: (a) planning program as work, (b) schedule of activities, and (c) the material activities; (2) the mechanism of implementation of the Teachers Working Group, which includes: (a) the pattern of activity, (b) the strategy activities, and (c) implementation of activities; and (3) organization personnel, which include: (a) the involvement of teachers, (b) the involvement of teachers guides subjects, (c) the involvement of tutors, and (d) the involvement of the builder.This study used a qualitative approach with a multi-site study design and analysis method inductive modified. The research was conducted in three groups, namely Primary School Cluster II, III Cluster and Cluster IV District of Dongko Trenggalek. The data collection was done by using in-depth interviews, observation, and documentation. Data analysis was performed interactively, through two stages of data analysis of individual sites and site traffic analysis. Checking the validity of test data is done with credibility, transferability, auditabilitas, and confirmability.The results of the study as follows: (1) The work program activities Teachers Working Group, including: (a) the work program activities Teacher Working Group for the professional development designed through a program that meets the needs of the teachers Core and SD fallout, related to the learning process or teaching and learning activities, (b) a schedule of activities Teacher Working Group compiled periodically and programmed by the Chairman of KKG and Working Group Principals as well as the coordinator of KKG aims to support the smooth running of each meeting activities, once a week based on the level of class or level of subjects without disturbing the lesson hours effective, and (c) material teacher Working Group activities in the cluster to meet the needs of the learning process or learning activities, the preparation involves primary teachers and primary core fallout; (2) The mechanism of activity Teachers Working Group, including: (a) the mechanism of implementation of the Teachers Working Group set up by the chairman of KKG by sending a letter of invitation in accordance with the schedule that has been signed, if there are problems faced by primary teachers Core and SD fallout, has not been resolved in the meeting, the activities can be completed through the forum of the Working group and the Working group Principal Supervisors, (b) the strategy activities teacher Working group to give assignments to teachers and SD SD Core Induced by using group discussions. For fostering cluster-level delivered by the coach (Principal, Working Group Principals, Working Group of School Supervisors and Educational and Cultural Services Unit) using the lecture method and if there are teachers who do not understand using question and answer, and (c) the activities of the Working Group Master in the cluster in an effort to increase professionalism of teachers that can be implemented in the core or in SD SD the impact and as a member of the group took turns in accordance with the mechanism established by the Department of Education and Culture Trenggalek; and (3) organization personnel, including: (a) the involvement of teachers in the implementation of Teachers Working Group can be selected as an administrator with certain criteria, which include: (1) Chairman/Vice Chairman of Working Master, (2) the Secretary/Deputy Secretary of the Working Group teachers, (3) Treasurer/Deputy Treasurer teachers Working Group, and (4) Coordinator of the Working Group on teacher grade 1 to grade 6 in one group, (5) Master Guides subject to certain subjects, and (6) Tutor, ( b) the involvement of Master Guides subjects provide benefits for primary teachers Core and SD fallout, which is experiencing problems related to the learning process or learning activity for specific subjects and classroom management, (c) the involvement of tutors provide benefits for teachers SD Core and SD fallout, which is experiencing problems related to the learning process or learning and teaching for all subjects whose implementation in the classroom or through tutorial activities in the activity Center Master (SD Core), and (d) the involvement of coaches in Group activities Work teachers have a role as advisor, facilitator, motivator for elementary school teachers and elementary Core fallout as well as efforts to increase the professionalism of teachers.
\end{abstract}


Based on these results, it is suggested to all parties, namely: (1) the Head of Education and Culture Trenggalek, should conduct monitoring and evaluation of each implementation of the Teachers Working Group in an effort to increase the professionalism of teachers; (2) Primary Schools Core/Chairman of the Cluster and SD fallout, should improve the competence of school management, educational leadership with managerial skills, which include: interpersonal skills, and conceptual skills. Through some of these skills, the Head SD Core/Chairman of the Cluster and SD Induced gain insight, making it more professional in managing and put every potential teachers to realize the quality of the school; (3) Working Group administrators Teachers should improve their skills in the management of Teachers Working Group activities in the cluster according to the needs of primary teachers and primary core impact is contained in the cluster in an effort to increase the professionalism of teachers; (4) the teacher should improve research skills by conducting research related to teaching and learning or teaching and learning in primary school, khsusnya in the cluster; (5) the development of management science can be used for development related to the management how to prepare a work program Master Group activities in a cluster in an effort to increase professionalism of teachers in elementary schools in the cluster; and (6) other researchers should be able to develop and delve deeper into the aspects relating to improving the professionalism of teachers through Teacher Working Group on three groups from elementary schools in areas difficult to reach, particularly in: (1) Cluster II Petung 1 Trenggalek (SD core and 8 SD fallout), (2) Cluster III Dongko 1 Psychology (SD SD Induced core and 8), and (3) Cluster IV Sumberbening 1 Psychology (SD SD Induced core and 7).

Keywords - professionalism of teachers, school groups, it is difficult to reach

\section{INTRODUCTION}

Education is the most effective efforts to improve the quality of human resources and the quality of it, determine its ability to compete. Education also determines the field of development is essential for the sustainability and excellence of a nation (Sonhadji, 2007). The function of education is to guide children toward a goal that we value highly. A good education is a successful effort to bring all the students to the tujuann. What diajarakan should be fully understood by all learners. Educational functions mentioned above, clarified by the Constitution of the Republic of Indonesia in 1945 Article 31, paragraph 1 states that every citizen is entitled to education and further in article 31, paragraph 2 , states that every citizen is obliged to follow basic education and the government must finance it.

Primary school education is the most important presence in the national education framework. Everyone recognizes that without basic education one may not be able menegikuti Secondary Education and Higher Education. To enter next jenjag education, students need to be equipped with a basic capability to be able to think critically and imaginatively to be applied in the way of writing and reading is an ability as the demands of the information age. Implementation of Elementary School in a professional becomes a necessity and inevitability in an effort to achieve quality basic education institution in accordance with societal expectations. Noting the enormous role, then the elementary school should be well prepared. Noting the above description, the quality of education at a higher level is largely determined by the quality of penidikan basis, so that elementary school teachers must be qualified. Elementary School teacher has the task of planning and implementing learning and assess learning outcomes. One of the educational issues facing the nation Indonesia is the low quality of education in each unit and the type of education, particularly at primary and secondary education (MONE 2000).

Education quality problems, seems to have become a very important issue in quite a long period. Noting the results of a survey conducted by the Human Development Index in 2009 and 2010, particularly the assessment of indicators of education, the Indonesian nation has competitive edge is very low, when compared with the nations that are in the countries of Southeast Asia, so that Indonesia still facing a very serious problem in terms of the quality of human resources. Judging from the non-academic aspects, a lot of criticism of the problems related to discipline, morals and ethics, creativity, independence and democratic attitude that does not reflect the level of quality expected by the public. School environment to implement education which is nonacademic (creativity, independence and democracy) is also relatively low. This is due to the quality of execution, the staff and especially the teacher is not able to translate the concepts methodological at the school level, although it has been held the program: (1) pre-service education, (2) in-service education, and (3) inservice training (Sahertian, 2004).

The findings of several indicators of the low efficiency of the basic education of the interim results 1960 until tahhun 1990s conducted by some experts suggest several conclusions, including: (1) developed countries, academic performance is determined more by factors outside the school (aspiration of family and interaction between children and parents) as compared to factors sekekolah itself, (2) countries are being developed or undeveloped, academic achievement, more determined factors of school (teachers, textbooks, learning tools and school management ) rather than factors outside the school. Noting the various indicators described above, then 
the cause of the low quality of education in terms of aspects of management education can be grouped into 3 (three) factors: (1) a system of education, (2) the education management system including systems professional development of teachers, and (3) factors substance management education. The main issue has always been the talk when it comes to the decline in the quality of basic education graduates a vote then all fixed on the figure of a teacher, because the teacher is considered as a determinant of the quality of basic education. Observing these conditions, the teacher considered also as the spearhead for the intellectual life of the nation. The importance of the position of elementary school teachers in upper accented by the Constitution of the Republic of Indonesia Number 14 of 2005 on Teachers and Lecturers in chapter II of article 2, paragraph (2) states that teachers have a position as professionals in primary education, secondary education and education Children Early in formal education in accordance with the legislation and chapter IV, article 8 states that teachers are required to have academic qualifications, competence, physical and spiritual health, have the ability to achieve national education goals.In Trenggalek, East Java Province, conditions of teachers until 2014 to the level of primary education amounted to 5,543 people with a breakdown of the number of elementary school teachers are civil servants there are 3,035 State and non-civil servant primary teachers as much as 2,508 people. The number of primary schools as many as 427, as many as 17 private primary schools and MI as many as 151 . (Source: List I In July 2014, the Department of Education and Culture Coaching SD Trenggalek). Referring to these conditions, the number of primary school teachers so great an educational resource that needs optimal handling. Human resources in this case an elementary school teacher is the most important organizational asset because it affects the efficiency, effectiveness and productivity of the organization. Tilaar (2001), revealed that human resources are now used and recognized as the most valuable organizational asset. School quality components depend on the size of one of them to the teacher factor. Teachers are human resources that have a strategic position in an effort to empower all potential school.Efforts to improve the quality of basic education is a shared duty to answer any challenge, especially in addressing the deterioration of the quality of education and educational purposes in Indonesia. This is in accordance with law No. 20 of 2003 on National Education System. Within the law, in Chapter II, Article 3 states that the national education goals is the development of students' potentials to become a man of faith and fear of God Almighty, noble, healthy, knowledgeable, skilled, creative, independent, and become citizens democratic and accountable and in chapter IV, article 17, paragraph (1) states that primary education is education that underlies secondary education and (2) stipulates that primary education in the form of elementary School (SD), Islamic elementary School (MI) or other forms equal, Junior High School (SMP), MTs (MTs) or other equivalent form. Since the legalization laws of the Republic of Indonesia Number 20 Year 2003 on National Education System is a new complex tantangn for teachers. Within the law, mandates that educators, especially teachers are the professionals in charge of planning, implementing the learning process, coaching and training, conduct research, and community service. Efforts to address the low quality of teachers at the top, especially elementary school teachers, it can be done by improving the ability proesional elementary school teachers through: (1) education, training and technical coaching on an ongoing basis at the school as well as on-site professional development of teachers through containers, such as: (1) Teachers Working Group (KKG), (2) Working Group Principal (PSC), and (3) Working Group Supervisors (KKPS) set out in the Director General of Primary and Secondary Education Department of Education No. 079/C/KEP/I/1993 dated 7 april 1993 on the Guidelines for System Development of professional Teacher through Formation Schools Elementary Schools, so as to improve the professional competence as stipulated in the Regulation of the Minister of National Education of the Republic of Indonesia number 16 Year 2007 regarding Standard Academic qualifications and Competencies Teachers. Professional competence is the ability to be possessed by the teacher in the planning and implementation of the learning process.

The problem is in line with the findings of previous studies conducted by Djuariah (2001), which explains that the system of professional development of teachers is implemented through group activities is an activity the provision of assistance and guidance which carried out a detailed and systematic targeting which focused on efforts to increase professional capability and development career teachers. In another study by Nurhatati (2005), which explains that in the professional development of teachers should be held based on the basis of perceived needs of teachers themselves. Teacher development approach "bottom-up" is a strategic way to apply. The teacher's voice about what is required and how it hits about the needs of what is perceived in the field and how its fulfillment need to be heard or considered. While the approach to professional development of teachers who are "top-down" as has been done today, it's time to be reformulated or modified forms and mechanisms, so as to suit the needs of the perceived professional development of teachers themselves.

Based on the description of the research context, encourages the writer to choose and discuss the professional development of teachers through school clusters with multi-site studies. The main focus of this research is how the professional development of teachers through school clusters in primary schools is difficult to reach. Focus is detailed as follows: (1) The work program of Teacher Working Group in enhancing the professionalism of elementary school teachers in three groups in Trenggalek, which include: (a) planning the work program activities Teacher Working Group in enhancing the professionalism of elementary school 
teachers in three groups in Trenggalek, (b) Schedule of events teacher Working Group in enhancing the professionalism of elementary school teachers in three groups in Trenggalek, and (c) Materials teacher Working Group activities in improving the professionalism of elementary school teachers in three groups in Trenggalek; (2) The mechanism of implementation of the Teachers Working Group in enhancing the professionalism of elementary school teachers in three groups in Trenggalek, which include: (a) pattern of activity Teacher Working Group in enhancing the professionalism of elementary school teachers in three groups in Trenggalek, (b) Strategy teachers Working Group activities in improving the professionalism of elementary school teachers in three groups in Trenggalek, and (c) Implementation of teacher Working Group activities in improving the professionalism of elementary school teachers in three groups in Trenggalek; (3) The organization of personnel in the implementation of Teachers Working Group in enhancing the professionalism of elementary school teachers in three groups in Trenggalek, which include: (a) The involvement of teachers in the implementation of Teachers Working Group to improve the professionalism of elementary school teachers in three groups in Trenggalek (b) the involvement of teachers guides subjects in implementation of the teachers Working Group to improve the professionalism of elementary school teachers in three groups in Trenggalek, (c) the involvement of tutors in the implementation of the teachers Working Group to improve the professionalism of elementary school teachers in the three groups in the District Terri, and (d) the involvement of supervisors in the implementation of the teachers Working Group to improve the professionalism of elementary school teachers in three groups in Trenggalek.

Based on the research focus, the purpose of this study was to describe things as follows: (1) Describe the work program of Teacher Working Group in enhancing the professionalism of elementary school teachers in three groups in Trenggalek, which include: (a) planning program as work, (b) schedule of activities, and (c) the material activities; (2) Describe the mechanism of implementation of the Teachers Working Group in enhancing the professionalism of elementary school teachers in three groups in Trenggalek, which include: (a) the pattern of activity, (b) the strategy activities, and (c) implementation of activities; and (3) Describe the organization's personnel in the conduct of Teachers Working Group in enhancing the professionalism of elementary school teachers in three groups in Trenggalek, which include: (a) the involvement of teachers, (b) the involvement of teachers guides subjects, (c) the involvement of tutors, and (d) the involvement of Trustees.

Based on the focus and purpose of the study, the results of the study are expected to be useful for various parties, among others, for: (1) For the Directorate of Elementary Education and Culture Ministry, is expected to unveil a new meaning of coaching teachers according to the needs on the ground which can be raised as an issue actual, to further formulated in a policy as an effort to enhance guidance systems professional capabilities of teachers within the framework of improving the quality of educational services at the elementary level, (2) for the Department of Education and Culture Trenggalek, as providers of education, the results of this research can be considered in decision-making in selecting the model or form of guidance and professional development of primary school teachers appropriate characteristics, potential and needs of the region, (3) For the builder, both school supervisors and principals, the results of this study are expected to provide input information for consideration in planning, implementing and evaluating development programs of elementary school teachers, particularly in Sub Dongko, Trenggalek, (4) for elementary school teacher, is expected to be used as input to improve keprofesiannya, so it will have an impact on improving the quality of teaching and learning, (5) for researchers the other, as the initial information about the professional development of teachers, and (6) for the development of management science education, the results of this study are expected to contribute ideas about coaching employees in this case the development of teachers as a repertoire of knowledge development, especially for science education management and management Resources Human.

\section{RESULT AND DISCUSSION}

The results showed that:

1.1 Work Program Working Group Activity in Improving Teacher Professionalism of Primary School Teachers

1.1.1 Planning work program

Implementation in cluster systems based program planning, schedule and material activities. KKG activities planned work program in accordance with the needs of primary teachers and primary core fallout associated with learning and teaching and learning process in the cluster. KKG work program designed jointly by the chairman of KKG with PSC chairman. The work program planned activities contained in the guidelines work group and then sent to each SD to SD Impact.

1.1.2 Schedule of events Teacher Working Group

The work program Teachers Working Group related to the schedule, highlighted also in the guidelines of the management group Elementary School that the number of weeks in a year is 52 weeks, should be a meeting for a group of classroom teachers is done once a week or every two weeks, so any classroom teachers 
experienced professional help 52 or at least 26 times a year. Work schedules KKG activities programmed in the program of work and scheduling the event, Chairman of the KKG has been coordinating with the school principal and coordinator of the Working Group on Teacher grade 1 to grade 6 in one group and then sent to each teacher who is in SD Core and SD the impact in a cluster. On the other hand the work schedule the event, held once a week every Saturday from 10.00 until $12.00 \mathrm{pm}$ after school hours effective. As for scheduling or allocating time activities at the Center for Teacher Activity in the primary core can be reached with several alternatives such as the following: (a) Meetings KKG held every day of the week after school hours ended by dividing the occasion, which include: (1) Monday to grade teacher I, (2) Tuesday to classroom teachers II, (3) Wednesday for classroom teachers III, (4) Thursday for classroom teachers IV, (5) Friday to classroom teachers V, and (6) Saturday for the sixth grade teacher; (B) Meetings KKG held once in a week, after the end of school hours by dividing the opportunity for teachers, consisting of: (1) the first week for teachers of class I and II, (2) the second week for teachers of class III and IV, ( 3) week III to class V and VI teacher, and (4) weeks of IV meeting related to the discussion of subjects between grade level teachers; (C) Another alternative that is considered to be more effective and efficient. Alternative frequency in a year and the use of alternative days of the week that are preferred in combination in the preparation of the schedule of work programs, for example selected frequency of 26 times a year for each teacher and class three days a week. Preparation of group work program should be drawn up based on the needs of teachers. Therefore, the preparation of group work program is based on the identification problem that really needed by the teacher, and then (if deemed necessary) used as a core program yearly/quarterly/monthly/ weekly.

1.1.3 Materials Teacher Working Group Activities

Material activities are being organized with the involvement of primary teachers and primary core fallout in one cluster. Material activities according to the needs of teaching and learning processes and materials programmatic activities in the work program KKG. material presented in KKG for professional development of teachers can be: (1) preparation of the semester program, (2) the preparation of daily, (3) planning learning activities and use, (4) the manufacture of tools for learning, (5) use of resources learning, (6) assessment of learning outcomes, and (7) others related to learning. In addition to this, through guidelines for the management of the group explained that the training materials that need to be addressed, including: (1) training outlines the curriculum, (2) learning methodology, (3) evaluation techniques, (4) media, (5) the management class , (6) the management of education, and (7) Professional Development System training. On the other hand aspects drilled to the teacher, principal and supervisor TK/SD, which includes: (1) classroom management, (2) school management, (3) management group, (4) System Development Professionals, and (5) RAPBS. Training materials as described above, the materials need to be conveyed in this component, consisting of: (1) writing scientific papers, (2) the making of props simple, (3) save/preserve raw/learning tools, and (4) utilization a book or a learning tool (Department of Education, and Bottlery, 2006). Noting the statements that have been mentioned above, the program KKG arranged as planned by the Chairman of the Working Group on Teacher and School Supervisors Chairman of the Working Group is essentially directed to improve the quality of learning and to improve the professional competence of teachers. Therefore, the Chairman of the Working Group Master and each Principal is obliged to do guidance to teachers who are in the school.

1.2 Implementation Mechanism Working Group Activity in Improving Teacher Professionalism of Primary School Teachers

\subsubsection{Patterns Teacher Working Group activities}

The mechanism of the implementation of KKG in accordance with the pattern applied by the Chairman of the Working Group on Teacher by means of circulating an invitation letter signed by the chairman of KKG and chairman of the group, the pattern of activity Teacher Working Group that conducted by the Chairman of KKG by making an invitation letter adapted to the schedule of activities that have been programmatic guidelines Teachers working Group, in the cluster. A letter of invitation made by the Chairman of the Working Group Master properties just reminded for teachers. Strategy Working Group activities Teachers.

KKG strategy for giving the task to the teacher using group discussions. KKG strategy is to provide guidance to use the lecture method, the strategy of its activities when there are teachers who have not understood the question and answer method.

\subsubsection{The implementation of the Working Group Master}

KKG in the cluster core implemented in SD with SD fallout as a member of the group, activities can be carried out in turns in a cluster. Teachers Working Group activities in the cluster, made up of a core SD and SD impact is defined by the Head of Education and Culture Trenggalek. KKG set up aims to improve the professionalism of elementary school teachers who are members of the cluster system. School cluster consists of two words, namely groups and schools. One group Elementary School ranged from 3 to 8 Elementary School that includes one primary core and some elementary fallout in a region adjacent. 
1.3 Organization of personnel in the implementation of Teachers Working Group in enhancing the professionalism of elementary school teachers in three groups in Trenggalek

1.3.1 The involvement of teachers

The involvement of teachers in the implementation of the Working Group Master may be appointed as a trustee of the activities of the Working Group of Teachers and teachers' involvement in the implementation of the Teachers Working Group selected the caretaker activities Teacher Working Group has had a certain criteria, the involvement of teachers in the implementation of Teachers Working Group, includes: (a) Chairman of the Teachers Working Group, (b) Secretary of the Teachers Working Group, (c) Treasurer Teachers Working Group, and (4) Working Group Coordinator Master grade 1 to grade 6 in one group.

1.3.2 The involvement of teachers guides subjects

Involvement of Teachers Guides Subjects very beneficial for elementary school teachers Inti and SD fallout in the cluster for a particular subject, the involvement of teachers guide Subjects very useful for elementary school teachers Inti and SD Induced who have difficulties in learning or classroom management, involvement of Master Guides Currency The lesson has tasks: (1) transmit and develop the results of upgrading or training, (2) mengimbaskan new ideas, and (3) to guide the activities of the Working Group according to subject teachers.

1.3.3 The involvement of tutors

The involvement of tutors in the cluster system is very useful to help elementary school teachers and elementary Core Induced experiencing difficulties related to teaching and learning, tutor involvement in the cluster system is very useful to help elementary school teachers and elementary Core Induced tutorial can be served in the center. Tutors are teachers who have the ability to master all subjects in the core SD and SD fallout.

1.3.4 Involvement of Trustees

Involvement builder can provide motivation for elementary school teachers Inti and SD fallout to participate in every meeting activities Teachers Working Group, the involvement of a builder on the implementation of the Group activities Kera Guru nature briefed elementary teacher Inti and SD fallout associated with the learning process and the involvement of the coach on the implementation of activities the Working group provides an advisory teacher for elementary school teachers and elementary Core fallout.

Based on the research findings across the entire site, described the context diagram as shown in Figure Teacher Professionalism Enhancement Through Teacher Working Group Activity in Three Primary School Cluster, the following.

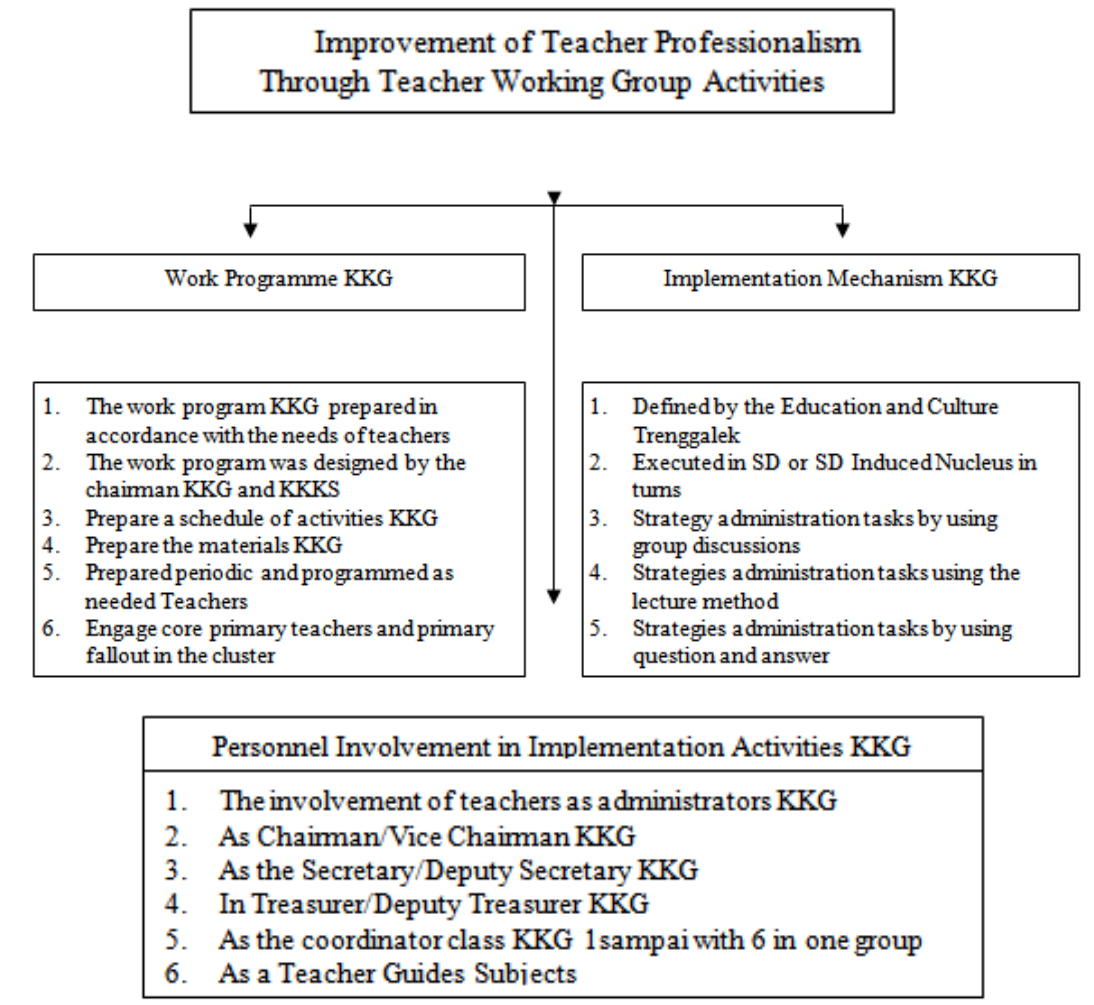




\section{CONCLUSION}

Based on the results of the exposure of data and research findings as well as findings pelitian discussion above, we can conclude the following. (1) Work Program Activity Teacher Working Group to Enhance Professionalism of Primary School Teachers: (a) The work program of activities of the Working Group Master for the professional development designed through a program that meets the needs of the teachers Core and SD fallout, related to the learning process or activity learn how to teach; (B) Schedule of events Teacher Working Group compiled periodically and programmed by the Chairman of the PSC and the coordinator KKG KKG and aims to support the smooth running of each meeting activities, once a week by grade level or hierarchy of subjects without interfering with effective teaching hours; (C) Materials Teacher Working Group activities in the cluster to meet the needs of the learning process or learning activities, the preparation involves primary teachers and primary core fallout. (2) Implementation Mechanism Working Group Activity in Improving Teacher Professionalism of Primary School Teachers: (a) The mechanism of implementation of the Teachers Working Group set up by the chairman of KKG by sending a letter of invitation in accordance with the schedule that has been signed. If there are problems faced by primary teachers and primary core fallout, has not been resolved in the meeting, the activities can be completed through the forum of the Working Group Working Group Principal and Supervisors; (B) Working Group activities Strategy Master to give assignments to teachers and SD SD Core Induced by using group discussions. For cluster-level coaching delivered by Pembina (Principal, PSC, KKPS and UDPK) using the lecture method and if there are teachers who do not understand using question and answer; (C) Activity Teacher Working Group in the cluster in an effort to increase the professionalism of teachers that can be implemented in the core or in SD SD The impact and as a member of the group took turns in accordance with the mechanism established by the Department of Education and Culture Trenggalek. (3) Organization of Personnel in the Implementation of Teacher Working Group to Enhance Professionalism of Primary School Teachers: (a) The involvement of teachers in the implementation of Teachers Working Group can be selected as an administrator with certain criteria, which include: (1) Chairman / Vice Chairman of the Working Guru, (2) the Secretary / Deputy Secretary of the Teachers Working Group, (3) Treasurer / Deputy Treasurer Teachers Working Group, and (4) Coordinator of the Working Group on Teacher grade 1 to grade 6 in one group, (5) Master Guides subject to subjects particular, and (6) Tutor; (B) Involvement Subjects Teachers Guides provide benefits for primary teachers and primary core fallout, which is experiencing problems related to the learning process or learning activity for specific subjects and classroom management; (C) Involvement Tutor provides benefits for primary teachers Core and SD fallout, which is experiencing problems related to the learning process or learning and teaching for all subjects whose implementation in the classroom or through tutorial activities in the Activity Center of Teachers (SD Core); and (d) involvement in the activities of the Working Group of Trustees of Teachers have a role as advisor, facilitator, motivator for elementary school teachers and elementary Core fallout as well as efforts to increase the professionalism of teachers.

\section{REFERENCES}

\section{Journal Papers:}

[1] Bore, A. 2006. Bottom.up for Creativity In-Service: A Collaborative: Methods for Curriculum and Professional Development. Journal of Education for Teaching. Volume 32. Number 32. Number 4. November 2006: University of Pull, UK.

[2] Cornford, S. C., \& Bruce. 2006. A Qualitative Study of The Experience of training in general pratice: a Community of Practice? Journal of Education for Teaching. Volume 32 Number 3. On August 3, 2006: University of Durham, UK, University of Newcastle, UK.

[3] Coronel, J. M., \& Marja J. C., Marisa, F\% Sebastian, G. 2003. Qualities of Collaboration, Professional Development and Teaching Improvement: an Experience in the University Context. Journal of Education for Teacing, Volume 29, Number 2. Jully 2003: Department of Education, University of Huelva, Campus de El Carmen s / 21007 Huelva, Spain.

[4] Edmond, N. 2003. School-Based Learning: Constraints and Limitations in Learning School form experince for Teaching Assistants. Journal of Education for Teaching. Volume 29. Number 2. Jully 2003: University of Brighton, School of Education Centre for Continuing Proffesional Development, Falmer. BNI 9 PH Brighton, UK.

[5] Ekosusilo, M. 2003. Contributions Study of Education, Upgrading, and activity against Peningkatana KKG Teacher Professional Ability. Journal of Educational Sciences. Volume 10, Number 1: LPTK (Institutions of Personnel) and ISPI (Association of Indonesian Education)

[6] Aaron C. Z. 2005. Improving the Quality of Human Resources through Education Is the Key to Success An Organization in the Era of Globalization and Regional Autonomy. Pendiikan and Cultural Journal (Online), No. 41. (http://www.go.id/Jurnal/41/Cut Zahri Harun.htm, accessed on March 17, 2014) 
[7] The Director General of Primary and Secondary Education Department of Education and Culture No. 079 / C / Kep / I / 1993 on Guidelines for Teacher Professional Development System Through Formation School Elementary School

[8] Moore, M .., and Barrie, W. 2003. Bookstart: a Qualitative Education. Education Review Journal. Volume 55. Number 1. 2003: Newman College, Birmingham, UK and Iniversity of Birmingham, UK.

[9] Morrison, L., \& Maggie, P. 2006. Flexibility in Initial Teacher Education Pedagogy and Practice Implications for. Journal of Education for Teaching, Volume 32 Number 2, May 2006: University of London, UK

[10] Seferoglu, G. 2004. Study of Alternative Certification Practices English teacher in Turkey. Jornal of Education for Teaching. Volume 30. Number 2, July 2 2004: Middle East Technical University, Faculty of Education, Department of Foreign Language Education

[11] Suharto, Y. 2000. Opinions academic community on Creativity Development Challenges Facing Higher Education Globalization. Science Journal Pendidikan.Nomor 2 Years 27 Malang

[12] White, C. 2005. The Role of the Teacher. Journal of Education for Teaching, Volume 31. Number 4. November 2005: Bath Spa University, UK

[13] Wiyono, B. D. 2000. Leadership Style Principal and Teacher Morale in Implementing Task Position in primary school. Journal of Educational Sciences. Year 17 No. 1 January 2000.

Books:

[14] Achmad, D.S. 2001 Guidelines for the Management School Cluster. Jakarta: Directorate General of Primary and Secondary Education Primary Education Ministry of Education and Culture.

[15] Arikunto, S. 2000. Teaching Management In Human. Jakarta: Rineka Reserved.

[16] Bafadal. I. 2003. Improvement of Primary School Teachers' Professionalism in the Framework of SchoolBased Quality Improvement Management. Jakarta: Earth Literacy.

[17] Bogdan, R. C., \& Biklen, S. K. B. 1982. Qualitative reseach for Education: Art introducation to Theory and Methods. Boston: Allyn and Bacon. Inc.

[18] Bogdan, R. C., \& Biklen, S. K. B. 1998. Qualitative reseach for Education: Art introducation to Theory and Methods. Boston: Allyn and Bacon. Inc.

[19] Bogdan, R. C., \& Taylor, S. J. 1975. Introduction to qualitive Reseach Methods. New York: John Wiley

[20] Creswell, J. W. 2009. Research Design: Qualitative, Quantitative, and Mixed Methods Approaches. Thousand Oaks, CA: Sage.

[21] Danim, S. 2003. Education System Reform Agenda Yogyakarta: Student Library

[22] Department of Education, 1996 / 1997. Guidelines for School Cluster. Directorate General of Primary and Secondary Education

[23] MONE. 2000. Strengthening Management School Cluster. Jakarta Secondary Education Directorate General. Directorate General of Primary and Secondary Education. Department of Education and Culture

[24] Djuariah, D. 2001. Development System Capabilities Through Teacher Professional Activity School Cluster. Thesis. Bandung: University of Indonesia.

[25] Dymoke, S., \& Jennifer, K. H., 2006. Professional Development and the Beginning Teacher: Issues of Teacher Autonomy and Institutional Conformity in the Performance Review Process. Journal of Education for Teaching. Volume 32. Number 1. February 2006: University of Leicoster, UK.

[26] Effendy, O.U. 2000 Science Communication: Theory and Practice. Bandung: Teenagers Publisher Works.

[27] Fajar, M. 2002. Government policy Amenities Basic Education Sector Edition II. Jakarta: Dikjen Dikdasmen mone.

[28] Glasser, H. G., \& Strauss, A. L., 1980. Discovery of Grounded Theory Strategy for Qualitative Research. New York: Aldine Publishing Co.

[29] Glickman, C. D. 1981. Development Supervision. Alexandria: Association for Supervision and Curriculum Development

[30] Gorton, R. A. 1976. School Administrattion: Challenge and Opportunity for Leadership Debuque, Iowa: Wm.C.Brown Company Publishers.

[31] Hamalik, O. 2006. Approach Competency Based Teacher Education. Jakarta: Earth Literacy.

[32] Lincoln, Y. S., \& Guba, E. G. 1985. Naturalistic Inquiry, London: Sage Publications. Inc.

[33] Miles, B. M., \& Huberman, A. M. 1992. Qualitative Data Analysis. Sourcebook of New Methods. Jakarta: Indonesia University Press.

[34] Moleong, L. J. 2002. Qualitative Research Methodology. Bandung: teen Rosda paper

[35] Nurhatati. 2005. Primary School Teacher Professional Development (Research About the Effectiveness of Teachers' Professional Development System SD In the municipality of Bandung, West Java). Thesis. Bandung: University of Indonesia. 
[36] Guidelines Penilisan Scientific Work: Theses, Dissertations, articles, Mkalah and Research Report. 2004 (ed 4), State University of Malang.

[37] Regulation of the Minister of National Education of the Republic of Indonesia Number 16 of 2007 on Academic Qualification Standards and Teacher Competency.

[38] Sagala, S. 2009. Ability of Professional Teachers and Education Personnel. Bandung: Alfabeta.

[39] Sahertian, P.A. 2000. Concepts and Technical Supervision of Education in the Context of Human Resources Development. Jakarta: Rineka Reserved.

[40] Sonhadji, K. H., H. A. 1994. Research in Educational Management Markerting presented at the Seminar on Role of Research in the Field of ManajemenPendidikan. Malang Teachers' Training College. December 15, 1994

[41] Sonhadji, K. H., H. A. 1996. Professionalism in the management of Educational Papers Presented at the National Education konverensi Indonesia III in Ujung Padang. On 4-7 March 1996

[42] Sonhadji, K. H., H. A.1996. Qualitative Research Report Writing Techniques. Malang: Kalimasahuda Press

[43] Sonhadji, K. H., H. A. 1996. Mechanical Data Collection and Data Analysis in Qualitative Research. Malang: Kalimasahuda Press

[44] Sonhadji, K. H., H. A. 2001. Management Education and Training. Malang: State University of Malang

[45] Sonhadji, K. H., H. A. 2007. Optimization of the Quality Assurance Framework Program S-1 PGSD. Paper presented at the Workshop on Optimization of Civil Procedure S-1 PGSD University PGRI Adibuana. Surabaya. 14 September 2007

[46] Sowiyah. 2005. Management Competency Enhancement Training Teachers (Multi-Site Study in Three public elementary school in Kota Makmur Wawai Province). Dissertation. Unpublished. Graduate Program, State University of Malang.

[47] Sudarwan, D. 2010. Teachers Professionalization and Code of Conduct. Bandung: Alfabeta.

[48] Sudarwan, D. 2011. Teacher Professional Development: From Induction into the Professional Madani. Jakarta: Media Perhalindo.

[49] Sudjana, N. 2001. Fundamentals of Teaching and Learning. Bandung: Sinar Baru

[50] Suharningsih, 2009. Teacher Performance Optimization in the Process of Learning in Elementary School in Malang (Multi-Site Study of Three Elementary School). Dissertation. Unpublished. Graduate Program, State University of Malang.

[51] Sugiono. 2007. Qualitative Research Methods. Bandung: Alfabeta.

[52] Prostration, A. 1990. The intensity of tubes Studies Teachers Working Group (KKG) and Primary School Teachers' Professional Development in Sleman Yogyakarta. Posted Research Report no. Yogyakarta. Research institutions IKIP Yogyakarta

[53] Tilaar, H. A. R. 2001. New Paradigm of Education. Jakarta: Rineka Reserved

[54] Law of the Republic of Indonesia Number 14 Year 2005 on Teachers and Lecturers. Jakarta: Rays Graphic

[55] Law of the Republic of Indonesia Number 20 Year 2003 on National Education System. Jakarta: Ministry of Education

[56] Law of the Republic of Indonesia Number 32 Year 2004 on Regional Government. Bandung: Citra Umbara

[57] Yin, R. K. 1984. Case Study Research Design and Methods. California: Sage Publications, Inc. 